Zuzanna Maj

Ius Matrimoniale

$28(2017) \mathrm{nr} 3$

DOI:10.21697/im.2017.28.3.03

Wydział Prawa Kanonicznego UKSW

\title{
Przeszkody małżeńskie w świetle Kodeksu Prawa Kanonicznego oraz Kodeksu rodzinnego i opiekuńczego
}

\section{Wstęp}

Nie ulega wątpliwości, że wiele przeszkód małżeńskich wskazanych w Kodeksie Prawa Kanonicznego nie zostało uregulowanych w Kodeksie rodzinnym i opiekuńczym, ponieważ wynikają one z prawa Bożego oraz z natury Kościoła katolickiego. Niemniej w tych dwóch systemach prawnych część zakazów małżeńskich jest tożsama. Najczęściej są to przeszkody wypływające z prawa naturalnego, którym podlega każdy człowiek, niezależnie od przynależności państwowej czy religijnej. Za najważniejszy z aktów prawnych regulujących relacje między małżeństwem kanonicznym a cywilnym uważa się Konkordat ${ }^{1}$ zawarty przez Stolicę Apostolską i Rzeczpospolitą Polską. Odmienność przepisów prawa kanonicznego i prawa państwowego oraz możliwość zaistnienia pomiędzy nimi kolizji nie musi oznaczać konfliktu².

1 Por. Ustawa z dnia 28 lipca 1993 r. - Konkordat między Stolicą Apostolską i Rzeczpospolita Polska (Dz. U. 1998 Nr 51, poz. 318), art. 10 pkt 1: „Od chwili zawarcia małżeństwo kanoniczne wywiera takie skutki, jakie pociąga za sobą zawarcie małżeństwa zgodnie z prawem polskim [...]”.

2 Por. W. Góralski, Instytucja małżeństwa $w$ prawie kanonicznym $i w$ prawie polskim, w: W. GóRALSKI (red.), Studia nad małżeństwem i rodziną, Warszawa 2007, s. 557. 


\section{Przeszkody zawarte w Kodeksie Prawa Kanonicznego z 1983 r. w ogólności ${ }^{3}$}

W Kodeksie Prawa Kanonicznego w kanonie $1055 \$ 1$ została zamieszczona definicja małżeństwa. Jest ono „przymierzem, przez które mężczyzna i kobieta tworzą ze sobą wspólnotę całego życia, skierowaną ze swojej natury do dobra małżonków oraz do zrodzenia i wychowania potomstwa, [małżeństwo - Z. M.] zostało między ochrzczonymi podniesione przez Chrystusa Pana do godności sakramentu"4. Prawodawca kościelny położył nacisk na następujące elementy: 1) przymierze - wspólnotę całego życia mężczyzny i kobiety; 2) ukierunkowanie jej ku konkretnym celom; 3) godność sakramentalną związku małżeńskiego ${ }^{5}$.

Aby chronić małżeństwo i wykluczyć sytuacje, w których dobro publiczne lub samych kontrahentów byłoby zagrożone, ustawodawca kościelny określił przeszkody uniemożliwiające ważne zawarcie związku małżeńskiego. W związku z tym, że ograniczają one prawa, wymagają bardzo ścisłej i jednoznacznej interpretacji ${ }^{6}$. W prawie kanonicznym istnieje dwanaście przeszkód małżeńskich: wieku; impotencji; węzła małżeńskiego; różnej religii; święceń; wieczystego publicznego ślubu czystości złożonego w instytucie zakonnym; uprowadzenia; występku; pokrewieństwa; powinowactwa; przyzwoitości publicznej; pokrewieństwa prawnego 7 . W KPK 1983 wyliczono

3 W Kodeksie Prawa Kanonicznego z 1917 roku wyróżniano przeszkody zrywające oraz wzbraniające. W obecnie obowiązującym kodeksie odstąpiono od podziału na rzecz przeszkód zrywających. Opisując tę materię, nie ma potrzeby używania zwrotu „przeszkody zrywające”, choć nie jest to błędem.

4 Codex Iuris Canonici auctoritate Ioannis Pauli PP. II promulgatus, 25 I 1983, AAS 75 (1983); tekst polski w: Kodeks Prawa Kanonicznego, Poznań 1984, kan. 1055 (dalej: KPK 1983).

5 Por. W. Góralski, Małżństwo w prawie kanonicznym, Prawo Kanoniczne 1-2 (54) 2011, s. 129.

6 Por. H. Stawniak, Przeszkody małżeńskie wynikające z węzła etyczno-prawnego, Prawo Kanoniczne 3 (55) 2012, s. 28.

7 Wymienione przeszkody zostały uregulowane w kanonach 1083-1094 KPK 1983. Należy zauważyć, że podobne unormowania zostały zawarte w Kodeksie Kanonów 
je taksatywnie. Najwyższy Prawodawca nie dopuszcza możliwości wprowadzenia innych przeszkód np. przez konferencje biskupów ${ }^{8}$ czy też biskupów diecezjalnych. Kompetencja autentycznego wyjaśniania oraz ustanawiania została wprost zastrzeżona najwyższej władzy kościelnej ${ }^{9}$. Ponadto źródłem ustanowienia przeszkody nigdy nie może być zwyczaj ${ }^{10}$.

Przeszkody te są ściśle związane z realizacją celu, jaki Kościół wyznaczył sakramentowi małżeństwa. Ze względu na różny charakter przeszkód oraz trwałość prawodawca kościelny wprowadził kilka ich podziałów. Za pierwsze kryterium uznaje się czas. „Przeszkodą można nazwać postanowienie prawa kanonicznego, które w oparciu o prawo Boże pozytywne, naturalne, względnie dla dobra publicznego lub dla dobra publicznego połączonego z prywatnym, pewne osoby czyni niezdolnymi do zawarcia małżeństwa, czy to czasowo (przeszkoda czasowa), czy to na stałe (przeszkoda trwała)"11. Następnie, biorąc pod uwagę kryterium zakresu podmiotowego, należy wyróżnić przeszkody absolutne, dotykające wszystkie osoby oraz przeszkody względne, odnoszące się do konkretnych kontrahentów. Ostatnie kryterium podziału nie zostało wprost sformułowane w KPK 1983, jednak

Kościołów Wschodnich (dalej: KKKW). Poszczególne przeszkody w pewnym stopniu różnią się zakresem obowiązywania w stosunku do istniejących w Kościele łacińskim. Ponadto w KKKW została wprowadzona jedna, która w obecnym kodeksie nie istnieje - przeszkoda pokrewieństwa duchowego. Por. Codex Canonum Ecclesiarum Orientalium auctoritate Joannis Pauli PP. II promulgatus, AAS 82 (1990); tekst polski w: Kodeks Kanonów Kościołów wschodnich promulgowany przez papieża Jana Pawła II, Lublin 2002.

8 Konferencjom biskupów przyznano np. możliwość podwyższenia wieku (określonego w KPK 1983) uprawniającego do zawarcia związku małżeńskiego. Co istotne, chodzi w tym przypadku jedynie o jego godziwość, a nie ważność. Konferencje biskupie nie mają zaś prawa obniżyć wieku koniecznego przy zawarciu związku w Kościele.

9 Por. KPK 1983, kan. 1075.

10 Por. W. GóRAlski, Kanoniczne przeszkody małżeńskie in genere, Prawo Kanoniczne 3 (55) 2012, s. 13.

11 M. Al. Żurowski, Kanoniczne prawo małżeńskie Kościoła katolickiego, Katowice 1987, s. 118-120. 
wskazuje na nie literatura kanonistyczna. Kanoniści wyodrębniają przeszkody wynikające $\mathrm{z}$ prawa Bożego oraz prawa kościelnego ${ }^{12}$.

\section{Przeszkody zawarte w Kodeksie rodzinnym i opiekuńczym w ogólności}

Polski ustawodawca w Kodeksie rodzinnym i opiekuńczym zamieścił jedynie siedem przeszkód małżeńskich. Ich najbardziej podstawowy podział dotyczy usuwalności. Przeszkodami bezwzględnymi, czyli nieusuwalnymi, są: ubezwłasnowolnienie całkowite, bigamia, pokrewieństwo oraz przysposobienie. Pozostałe, tj. przeszkoda wieku, choroba psychiczna albo niedorozwój umysłowy i powinowactwo są względne, co oznacza, że mimo ich wystąpienia w określonych przypadkach sąd może wydać zezwolenie na zawarcie związku małżeńskiego.

Istotna różnica pomiędzy przeszkodami wymienionymi w prawie kanonicznym oraz w polskim systemie prawnym odnosi się do ważności małżeństwa przy wystąpieniu jednej z nich. W myśl ustawodawcy kościelnego małżeństwa zawarte przy istnieniu przeszkody są nieważne od samego początku, zaś polski prawodawca wprowadza instytucję unieważnienia małżeństwa. Oznacza to, że zawarcie związku małżeńskiego pomimo wystąpienia przeszkody jest ważne, jednak można je unieważnić ${ }^{13}$.

\section{Przeszkody występujące w obydwu porządkach prawnych}

W obydwu systemach prawnych istnieje pięć tożsamych przeszkód: wieku, węzła małżeńskiego, pokrewieństwa, powinowactwa oraz pokrewieństwa prawnego (adopcji). W niektórych przypadkach ich

\footnotetext{
12 Por. C. Suchocki, Przeszkody matżeńskie $w$ prawie kanonicznym i polskim kodeksie rodzinnym i opiekuńczym. Poradnictwo rodzinne $w$ aspekcie wymogów Konkordatu, Lublin - Sandomierz 1997, s. 19.

13 Por. G. JęDrejek, Zawarcie małżeństwa, w: Prawo rodzinne, red. G. JęDrejek, Warszawa 2015, s. 54.
} 
zakres jest nieco inny w zależności od ustawodawcy, który określił przeszkodę.

Kodeks Prawa Kanonicznego różni się diametralnie od Kodeksu rodzinnego i opiekuńczego ze względu na zasięg obowiązywania prawa, bowiem zapisy pierwszego kodeksu obowiązują wszystkich katolików, a normy zawarte w drugim kontrahentów na terenie Rzeczpospolitej Polskiej.

\subsection{Przeszkoda wieku (impedimentum aetatis)}

Kanon $1083 \$ 1$ stanowi: „Nie może zawrzeć ważnego małżeństwa mężczyzna przed ukończeniem szesnastego roku życia i kobieta przed ukończeniem czternastego roku”. Wiek należy obliczać według normy podanej w kanonie $203 \mathrm{KPK} 1983^{14}$. Ustawodawca świecki wyznaczył dolną granicę wieku jednakową dla kobiety i mężczyzny - osiemnasty rok życia ${ }^{15}$. Zamieścił jednak klauzulę, która umożliwia kobiecie zawarcie związku małżeńskiego po ukończeniu szesnastego roku życia ${ }^{16}$, po uprzedniej zgodzie sądu opiekuńczego ${ }^{17}$. Zanim sąd wyda zezwolenie, musi się upewnić, czy rodzina, która powstanie po udzieleniu zezwolenia, będzie w stanie realizować podstawowe funkcje małżeństwa oraz czy będzie to trwała relacja, dająca szansę prawidłowego rozwoju dzieci, które mogą się pojawić w tym związku ${ }^{18}$.

14 Por. G. Dzierżon, Przeszkoda wieku, w: W. Góralski (red). Przeszkody matżeńskie w prawie kanonicznym, Warszawa 2016, s. 77.

15 Por. Ustawa z 25 lutego 1964 r. - Kodeks rodzinny i opiekuńczy (Dz. U. Nr. 9, poz. 59 ze zm.), art. $10 \$ 1$, zd. 1 (dalej: KRO).

16 W tym miejscu należy się odnieść do Kodeksu cywilnego. Określa on osiągnięcie pełnoletności przez kobietę, która nie ukończyła osiemnastego roku życia, a zawarła związek małżeński: „Przez zawarcie małżeństwa małoletni uzyskuje pełnoletność. Nie traci jej w razie unieważnienia małżeństwa”. Ustawa z 23 kwietnia 1964 r. Kodeks cywilny (Dz. U. Nr 16, poz. 93 ze zm.), art. $10 \$ 2$ (dalej: KC).

17 Por. KRO, art. $10 \$ 1, z d .2$.

18 Por. W. Stojanowska, Przeszkoda małżeńska ze względu na wiek $w$ prawie polskim, Prawo Kanoniczne 3 (55) 2012, s. 101. 
Najwyższy Prawodawca, mając świadomość różnic kulturowych, biologicznych, a przede wszystkim różnorodność systemów państwowych, wprowadził w $\$ 2$ omawianego kanonu specjalne uprawnienie. Zawarta w nim klauzula zezwala na odmienne unormowanie przeszkody wieku przez konferencję biskupów danego kraju. Ze względu na zbyt dużą dysproporcję dolnej granicy wieku nupturientów w prawie kanonicznym i w prawie rodzinnym, Konferencja Episkopatu Polski ustaliła, że w Polsce wiekiem wymaganym do godziwego zawarcia małżeństwa będzie osiemnaście lat, zarówno w przypadku kobiety jak i mężczyzny ${ }^{19}$. Było to podyktowane między innymi wprowadzeniem Konkordatu pomiędzy Stolicą Apostolską a Rzeczpospolitą Polską oraz zmianami w postanowieniach Kodeksu rodzinnego i opiekuńczego. W punkcie 9 „Instrukcji dla księży dotyczącej małżeństwa konkordatowego" Konferencja Episkopatu Polski zastrzegła, że ustalona dolna granica wieku dotyczy wszystkich małżeństw, nie tylko konkordatowych. Kobieta po uprzedniej zgodzie ordynariusza miejsca może godziwie zawrzeć związek małżeński po ukończeniu 16 lat $^{20}$. Jest to norma analogiczna do przepisów prawa polskiego. Należy podkreślić, że w myśl kanonów 1075 i $1077 \$ 2$ ograniczenie ustanowione przez konferencję biskupów wpływa jedynie na godziwość zawarcia małżeństwa ${ }^{21}$.

Przeszkoda wieku ma charakter absolutny, a naruszenie dyspozycji zamieszczonej w kanonie $1083 \$ 1$ chociażby przez jednego kontrahenta powoduje nieważność małżeństwa ${ }^{22}$. Omawiane obostrzenie jest czasowe - ustaje wraz z osiągnięciem przez stronę wymaganego wieku. Należy jednak zauważyć, że uprzednio zawarte małżeństwo nie staje

19 Por. Konferencja Episkopatu Polski, Instrukcja dla księży dotycząca małżeństwa konkordatowego, 12 XI 1998, pkt 8, w: C. KRAKowiAK, L. AdAMowiCz (red.), Dokumenty duszpastersko-liturgiczne Episkopatu Polski 1966-1998, Lublin 1999, s. 172.

20 Por. W. Góralski, Kanoniczne prawo małżénskie, Warszawa 2006, s. 119.

21 Por. J. Fornés, Poszczególne przeszkody zrywające, w: P. MAJer (red.), Codex Iuris Canonici. Kodeks Prawa Kanonicznego. Komentarz, Kraków 2011, s. 800.

22 Por. G. Dzierżon, Przeszkoda wieku, dz. cyt., s. 77. 
się ważne na mocy samego prawa. Konieczne w takiej sytuacji jest zastosowanie uważnienia w zawiązku bądź zwykłego ${ }^{23}$.

\subsection{Przeszkoda węzła małżeńskiego (impedimentum vinculi matrimonialis)}

Kodeks Prawa Kanonicznego stanowi: „nieważnie usiłuje zawrzeć małżeństwo, kto jest związany węzłem poprzedniego małżeństwa, nawet niedopełnionego"24. Przeszkoda ta pochodzi z prawa Bożego naturalnego, co powoduje, że nigdy nie można udzielić od niej dyspensy $^{25}$. Węzeł małżeński powstały w ważnie zawartym i dopełnionym małżeństwie jest nierozerwalny; nie może ulec rozwiązaniu nawet w sytuacji, gdy kontrahenci zadeklarują taką chęć. Przyczyną tego stanu rzeczy jest fakt, iż po ważnie wyrażonej zgodzie węzeł małżeński przestaje należeć do stron ${ }^{26}$. Co ważne, ze względu na źródło pochodzenia tej przeszkody, dotyczy ona nie tylko ochrzczonych, ale również nieochrzczonych. Pomiędzy osobami nieochrzczonymi lub w związku, w którym jedna osoba jest ochrzczona, ale druga nie, powstaje węzeł naturalny, zaś pomiędzy ochrzczonymi kobietą i mężczyzną wytwarza się węzeł sakramentalny ${ }^{27}$. Omawiana przeszkoda ustaje przez: „śmierć współmałżonka ${ }^{28}$, dyspensę papieską od małżeństwa zawartego i niedopełnionego, przywilej Pawłowy i stwierdzenie nieważności małżeństwa"29.

\footnotetext{
23 Por. TAmżE, s. 87.

24 KPK 1983, kan. $1085 \$ 1$.

25 Por. J. Fornés, Poszczególne przeszkody zrywające, dz. cyt., s. 802.

26 Por. U. Nowicka, Przeszkoda węzła małżeńskiego, w: W. Góralski (red.), Przeszkody małżńskie w prawie kanonicznym, Warszawa 2016, s. 164.

27 Por. TAmżE.

28 Śmierć współmałżonka może zostać uznana na podstawie następujących dokumentów: 1) aktu zgonu wystawionego przez władzę świecką, 2) autentycznego dokumentu władzy kościelnej uznającej śmierć tej osoby, 3) orzeczenia o domniemanej śmierci współmałżonka wystawionego przez biskupa diecezjalnego.

29 W. Gór ALsKI, Przeszkody małżeńskie wspólne w prawie kanonicznym $i$ w prawie polskim, w: W. GóRALSKI (red.), Studia nad małżeństwem i rodziną, Warszawa 2007, s. 628.
} 
Prawodawca świecki przepis zabraniający bigamii umieścił w artykule $13 \$ 1 \mathrm{KRO}$, który brzmi następująco: „nie może zawrzeć małżeństwa, kto pozostaje w związku małżeńskim"30. Przeszkoda ta została wprowadzona do prawa polskiego ze względu na zasadę monogamii, choć nie jest wprost wpisana do KRO. Wynika ona jednak bezsprzecznie z obszaru cywilizacyjno-kulturowego, w którym znajduje się Polska oraz naszej tradycji ${ }^{31}$. Co więcej, zostały wprowadzone sankcje za złamanie tego zakazu ${ }^{32}$. Należy zaznaczyć, że karze podlega osoba, która dopuszcza się bigamii, nie zaś osoba, która wstępuje w związek małżeński z osobą już związaną węzłem małżeństwa ${ }^{33}$.

W prawie polskim przeszkoda bigamii jest bezwzględna i nieusuwalna, co oznacza, że w żadnym przypadku sąd nie może wyrazić zgody na zawarcie małżeństwa mimo trwania przeszkody ${ }^{34}$. Jednak w odróżnieniu od prawa kanonicznego, w prawie polskim istnieje inny zakres przypadków ustania poprzedniego małżeństwa. Może ono nastąpić wskutek: śmierci jednego współmałżonka, uznania za zmarłego jednego z małżonków oraz rozwiązania małżeństwa prawomocnym orzeczeniem o rozwodzie ${ }^{35}$. Na uwagę zasługuje $\$ 2$ przywołanego artykułu, który brzmi: „unieważnienia małżeństwa $\mathrm{z}$ powodu pozostawania przez jednego $\mathrm{z}$ małżonków w poprzednio zawartym związku małżeńskim może żądać każdy, kto ma w tym interes prawny”. Prawodawca państwowy określił bardzo szeroki krąg osób, które mogą wystąpić z powództwem o unieważnienie

\footnotetext{
30 KRO, art. $13 \$ 1$.

31 Por. E. Sugier, Przeszkody małżńskie w polskim kodeksie rodzinnym i opiekuńczym. Małżeństwo konkordatowe, Koszalin 1999, s. 36-37.

32 Por. Ustawa z 6 czerwca 1997 r. - Kodeks karny (Dz. U. Nr 88, poz. 553 ze zm.), art. 206: „Kto zawiera małżeństwo, pomimo że pozostaje w związku małżeńskim, podlega grzywnie, karze ograniczenia wolności albo pozbawienia wolności do lat 2".

33 Por. E. Sugier, Przeszkody małżeńskie..., dz. cyt., s. 37.

34 Por. G. JęDREJeK, Zawarcie małżeństwa, dz. cyt., s. 54.

35 Por. J. GAJdA, Unieważnienie małżéstwa, w: T. SMyczyński (red.), Prawo rodzinne i opiekuńcze, t. 11, Warszawa 2014, s. 168-169.
} 
małżeństwa, co ukazuje, jak istotna jest przeszkoda bigamii w prawie polskim $^{36}$.

W literaturze panuje pogląd, że artykuł 13 KRO odnosi się jedynie do małżeństwa cywilnego. Osoba, która zawiera małżeństwo przed duchownym i składa oświadczenie woli przewidziane w artykule $1 \$ 2 \mathrm{KRO}$, nie zawiera małżeństwa na gruncie prawa cywilnego, o ile kierownik Urzędu Stanu Cywilnego nie sporządzi stosownego $\mathrm{aktu}^{37}$. Ślub kościelny, bez zachowania wymogów zawartych w KRO, w świetle prawa świeckiego nie wywołuje skutków prawnych ${ }^{38}$.

\subsection{Przeszkoda pokrewieństwa (impedimentum consanguinitatis)}

Przeszkoda pokrewieństwa oparta jest na wspólnocie krwi i zachodzi pomiędzy bliskimi osobami pochodzącymi od siebie lub wspólnego przodka ${ }^{39}$. Aby określić pokrewieństwo lub powinowactwo osób, należy obliczyć linię - prostą i boczną - oraz stopień. Obecnie obliczeń linii bocznej dokonuje się według rzymskiej komputacji pokrewieństwa - liczy się zrodzenia, nie licząc wspólnego przodka ${ }^{40}$. Przeszkoda pokrewieństwa w prawie kanonicznym została uregulowana w kanonie 1091. Paragraf pierwszy stanowi: „w linii prostej pokrewieństwa nieważne jest małżeństwo między wszystkimi wstępnymi i zstępnymi, zarówno prawego pochodzenia, jak i naturalnymi"41. Nieważne będzie również małżeństwo w linii bocznej, aż do czwartego stopnia włącznie ${ }^{42}$. Przeszkoda pokrewieństwa w linii prostej oraz w drugim stopniu linii bocznej pochodzi z prawa naturalnego, dlatego też nie udziela się od niej dyspensy. Nigdy nie można zezwolić na małżeństwo, jeśli istnieje wątpliwość, czy kontrahenci nie są ze

\footnotetext{
36 Por. G. JęDreJek, Zawarcie małżeństwa, dz. cyt., s. 62.

37 Por. J. GAJdA, Unieważnienie małżeństwa, dz. cyt., s. 168.

38 Por. TAMżE, s. 139.

39 Por. W. Góralski, Kanoniczne prawo małżéskie, dz. cyt., s. 140.

40 Por. H. Stawniak, Przeszkody małżeńskie..., dz. cyt., s. 26.

41 KPK 1983, kan. $1091 \$ 1$.

42 Por. TAMżE, kan. $1091 \$ 2$.
} 
sobą związani w linii prostej lub w drugim stopniu linii bocznej ${ }^{43}$. Od trzeciego i czwartego stopnia linii bocznej dyspensy może udzielić ordynariusz miejsca ${ }^{44}$. Przeszkoda pokrewieństwa nie zwielokrotnia się, co zostało wprost zawarte w kanonie 1091 \$3 KPK 1983.

Ustawodawca polski przeszkody pokrewieństwa oraz powinowactwa zamieścił łącznie w artykule 14 KRO. Ich zakres jest nieco węższy niż w prawie kanonicznym, bowiem małżeństwa nie mogą zawrzeć ze sobą krewni w linii prostej oraz rodzeństwo. W polskim systemie prawnym nie istnieją więc obostrzenia między krewnymi w trzecim i czwartym stopniu linii bocznej. Przeszkoda pokrewieństwa ma charakter bezwzględny. W razie jej wystąpienia sąd nigdy nie może udzielić zezwolenia na małżeństwo, podobnie jak w przypadku bigamii. „O ile jednak małżeństwo bigamiczne w określonych sytuacjach może ulec konwalidacji, to małżeństwo kazirodcze nigdy nie może zostać uważnione" ${ }^{45}$. Unieważnienia ślubu z powodu pokrewieństwa może żądać każdy, kto ma w tym interes prawny ${ }^{46}$. Jak podkreśla się w literaturze, zakaz zawierania związków małżeńskich przez osoby spokrewnione jest obecnie najstarszą z przeszkód ${ }^{47}$.

\subsection{Przeszkoda powinowactwa (impedimentum affinitatis)}

Powinowactwo to bliskość osób, która wynika z ważnie zawartego związku małżeńskiego (nawet niedopełnionego), a nie ze wspólnoty krwi. Istnieje pomiędzy mężem a krewnymi żony oraz żoną a krewnymi męża ${ }^{48}$. Przepisy zawarte zarówno w Kodeksie Prawa Kanonicznego, jak i w Kodeksie rodzinnym i opiekuńczym wskazują, że

\footnotetext{
43 Por. TAmże, kan. $1091 \S 4$.

44 Por. J. Fornés, Poszczególne przeszkody zrywające, dz. cyt., s. 810.

45 W. Gór ALsKi, Przeszkody małżeńskie wspólne w prawie kanonicznym i w prawie polskim, dz. cyt., s. 633.

46 Por. KRO, art. $14 \$ 2$.

47 Por. J. Gajda, Unieważnienie małżéstwa, dz. cyt., s. 172.

48 Por. C. Suchocki, Przeszkody małżeńskie..., dz. cyt., s. 64.
} 
przeszkoda powinowactwa istnieje tylko w linii prostej ${ }^{49}$, czyli pomiędzy małżonkiem a wstępnymi i zstępnymi drugiego małżonka ${ }^{50}$. W myśl kanonu $109 \$ 2$ powinowactwo oblicza się w ten sposób, że krewni męża są powinowatymi żony w tej samej linii i w tym samym stopniu i odwrotnie. Natomiast w polskim systemie prawnym metoda obliczeń została zawarta w artykule $61^{8} \$ 2$ KRO. Zamieszczona tam instrukcja brzmi: „linię i stopień powinowactwa określa się według linii i stopnia pokrewieństwa”. Co istotne, w KRO uwypuklono fakt, iż powinowactwo trwa mimo ustania małżeństwa ${ }^{51}$. Chodzi o sytuację rozwiązania małżeństwa prawomocnym wyrokiem sądu lub o śmierć współmałżonka. Stosunek powinowactwa zostaje jednak zniesiony w przypadku unieważnienia małżeństwa ${ }^{52}$.

W obydwu systemach prawnych nie jest to przeszkoda bezwzględnie obowiązująca. Na gruncie prawa kanonicznego dyspensy może udzielić ordynariusz miejsca. Bardzo często jest ona udzielana ze względu na dzieci zrodzone $\mathrm{z}$ pierwszego małżeństwa ${ }^{53}$. W prawie polskim z ważnych powodów zgody na małżeństwo pomiędzy powinowatymi może udzielić sąd ${ }^{54}$.

\subsection{Przeszkoda pokrewieństwa prawnego (impedimentum cognationis legalis)}

Ostatnią przeszkodą istniejącą w obydwu systemach prawnych jest przeszkoda wynikająca z pokrewieństwa prawnego. Jej podstawę stanowi zatem stosunek adopcji powstały na mocy przepisów państwowych. Między rodzicami adopcyjnymi a przysposobionym dzieckiem powstaje taki stosunek, jak pomiędzy naturalnymi rodzicami

\footnotetext{
49 Warto wspomnieć, że w Kodeksie Kanonów Kościołów Wschodnich przeszkoda powinowactwa istnieje nie tylko w linii prostej, ale także w drugim stopniu linii bocznej. Por. KKKW, kan. $809 \$ 1$.

50 Por. KPK 1983, kan. 1092; KRO, art. $14 \$ 1$, zd. 1.

51 Por. KRO, art. $61^{8} \$ 1$.

52 Por. M. Domański, Względne zakazy małżeńskie, Warszawa 2013, s. 330.

53 Por. J. Fornés, Poszczególne przeszkody zrywające, dz. cyt., s. 811.

54 Por. KRO, art. $14 \$ 1$, zd. 2.
} 
a ich dzieckiem biologicznym. Trudno zatem zgodzić się na swobodne zawieranie związków małżeńskich przez takie osoby, choć nie istnieją tu względy natury eugenicznej.

„Nie mogą ważnie zawrzeć małżeństwa ze sobą ci, którzy są związani pokrewieństwem prawnym powstałym $\mathrm{z}$ adopcji, $\mathrm{w}$ linii prostej lub w drugim stopniu linii bocznej" ${ }^{\prime 5}$. W związku z tym przepisem przeszkodą adopcji są związani: adoptujący i osoba adoptowana oraz osoba adoptowana i dzieci osoby adoptującej ${ }^{56}$. Przeszkoda ta może sięgać dalej, ponieważ nie został ograniczony stopień linii prostej. Pochodzi ona z prawa kościelnego, dlatego w szczególnych przypadkach można od niej udzielić dyspensy. Kompetencja ta przysługuje ordynariuszowi miejsca ${ }^{57}$. Należy zauważyć, że w systemie prawa kanoniczego przeszkoda ta nie jest uzależniona od uznania jej przez prawo świeckie danego kraju ${ }^{58}$.

W prawie polskim przeszkoda ta ma węższy zakres, dotyczy bowiem tylko przysposabiającego i przysposobionego ${ }^{59}$. „Przez przysposobienie powstaje pomiędzy przysposabiającym a przysposobionym taki stosunek, jak między rodzicami a dziećmi" ${ }^{60}$. Jest to zakaz bezwzględny, ustawa nie przewiduje udzielenia przez sąd zezwolenia na zawarcie małżeństwa pomiędzy przysposobionym a przysposabiającym. Jednak w myśl artykułu 125 KRO stosunek przysposobienia można rozwiązać, co powoduje usunięcie przeszkody pokrewieństwa ustawowego. Jak podaje się w literaturze, ustawodawca polski, wprowadzając omawianą przeszkodę do sytemu prawnego, uwydatnił fakt, iż stosunek przysposobienia nie jest tożsamy z pokrewieństwem określonym w artykule $14 \mathrm{KRO}^{61}$.

\footnotetext{
55 KPK 1983, kan. 1094.

56 Por. C. Suchocki, Przeszkody małżénskie..., dz. cyt., s. 66.

57 Por. J. Fornés, Poszczególne przeszkody zrywające, dz. cyt., s. 812.

58 Por. T. PAwluk, Prawo kanoniczne według kodeksu Jana Pawła II, t. 3, Olsztyn 2016, s. 152.

59 Por. KRO, art. $15 \$ 1$.

60 TAMŻE, art. $121 \$ 1$.

61 Por. J. Gajda, Unieważnienie mał̇̇eństwa, dz. cyt., s. 179.
} 


\section{Przeszkody występujące wyłącznie w Kodeksie Prawa Kanonicznego}

Prawodawca kościelny wprowadził siedem przeszkód, które nie znalazły odzwierciedlenia w prawie polskim. Pierwszą zawartą jedynie w KPK 1983 jest impotencja. Została wprowadzona, ponieważ uniemożliwia ona realizację najważniejszych celów małżeństwa, a jej podstawą jest prawo naturalne. Przeszkody: różnej religii, święceń oraz wieczystego publicznego ślubu czystości złożonego w instytucie zakonnym z oczywistych powodów nie występują na gruncie prawa świeckiego. Wymienione przeszkody uregulowano w prawie kanonicznym, ponieważ zostały określone i usankcjonowane przez Kośció1 ${ }^{62}$. Dlatego też możliwe jest udzielenie dyspensy od tych przeszkód. Warto zauważyć, że wszystkie trzy przeszkody, mimo iż są przeszkodami z prawa kościelnego, zawdzięczają swą podstawę i rację ustanowienia prawu Bożemu. Kolejne dwie przeszkody małżeńskie - uprowadzenia i występku - również występują tylko w prawie kanonicznym. Na gruncie prawa polskiego przepisy dotyczące uprowadzenia oraz zabójstwa uregulowano w Kodeksie karnym. Ostatnią, uregulowaną jedynie na gruncie prawa kościelnego, jest przeszkoda przyzwoitości publicznej. Kościół stoi na straży godności człowieka, a także moralności.

\subsection{Przeszkoda impotencji (impedimentum impotentiae)}

Brak przeszkody impotencji (inaczej zwanej niemocą płciową) w prawie polskim wynika z przepisów konstytucyjnych ${ }^{63}$, które gwarantują nieingerowanie państwa w sferę intymną swoich obywateli. Ponadto prawodawca świecki nie wytycza celu małżeństwa, jak czyni to prawodawca kościelny. Jednym z głównych zadań małżeństwa,

\footnotetext{
62 Por. J. GręźLIKowski, Przeszkody małżeńskie wynikające z węzła religijnego, Prawo Kanoniczne 3 (55) 2012, s. 77.

63 Por. Ustawa z 2 kwietnia 1997 r. - Konstytucja Rzeczpospolitej Polskiej (Dz. U. $\mathrm{Nr} 78$, poz. 483 z późn. zm.), art. 33, 41, 47.
} 
choć oczywiście nie jedynym i najważniejszym, jest zrodzenie i wychowanie potomstwa ${ }^{64}$. Cel ten, organicznie związany z ogólną koncepcją małżeństwa, traktuje się jako jednoczesne uprawnienie i obowiązek małżonków ${ }^{65}$. Jak wskazuje kanon 1096 \$1, zrodzenie potomstwa ma nastąpić przez jakieś seksualne współdziałanie ${ }^{66}$. Zapis ten ściśle koresponduje ze stanowiskiem Kościoła w odniesieniu do naturalnych metod poczęcia. „Z punktu widzenia prawnego niemoc płciowa jest niezdolnością dokonania aktu małżeńskiego, tzn. niezdolnością dokonania stosunku płciowego z wszystkimi jego istotnymi elementami zgodnie z tym, jak wyznacza je natura"67. Przeszkoda impotencji pochodzi z prawa naturalnego, dlatego też nie można od niej dyspensować ${ }^{68}$.

Aby rozpatrywana przeszkoda powodowała nieważność małżeństwa kanonicznego, musi ona być najpierw uprzednia - istnieć już przed zawarciem umowy małżeńskiej - oraz trwała, czyli w zasadzie nieuleczalna na drodze powszechnie dostępnych środków i metod leczniczych ${ }^{69}$. Ponadto przeszkoda ta musi być pewna. Nie można zabronić zawarcia małżeństwa lub orzec jego nieważność na podstawie wątpliwej niemocy płciowej nupturienta ${ }^{70}$. Warto zauważyć, że nie jest istotna przyczyna impotencji. Może mieć ona charakter organiczny, spowodowany wadliwą budową narządów rozrodczych danej osoby, lub charakter funkcjonalny, wynikający ze stanu psychicznego nupturienta ${ }^{71}$. Co ciekawe, Najwyższy Prawodawca nie uzależnił istnienia przeszkody

64 Por. H. Stawniak, Niemoc płciowa jako przeszkoda do małżeństwa. Ewolucja czy zmiana koncepcji?, Warszawa 2000, 162 -173.

65 Por. H. Stawniak, Uprawnienie-obowiązek zrodzenia i wychowania potomstwa w świetle kanonicznego prawa małżéskiego, Prawo Kanoniczne 3-4 (32) 1989, s. 126. 66 Por. KPK 1983, kan. $1096 \$ 1$.

67 J. Fornés, Poszczególne przeszkody zrywające, dz. cyt., s. 801.

68 W myśl kan. 85 KPK 1983 dyspensa jest rozluźnieniem prawa czysto kościelnego. Por. T. Pawluk, Prawo kanoniczne ..., dz. cyt., s. 129.

69 Por. W. Góralski, Kanoniczne prawo małżéskie, dz. cyt., s. 121.

70 Por. KPK 1983, kan. $1084 \$ 2$. Na ten temat pisze: J. Fornés, Poszczególne przeszkody zrywajace, dz. cyt., s. 801.

${ }^{71}$ Por. W. Góralski, Kanoniczne prawo małżeńskie, dz. cyt., s. 122. 
niemocy płciowej od wiedzy nupturientów na ten temat. Nieświadoma impotencji może być zarówno osoba nią dotknięta, jak i druga strona ${ }^{72}$.

Należy podkreślić, że niemoc płciowa nie jest tożsama z niepłodnością. Niepłodnością są takie defekty, które uniemożliwiają poczęcie potomstwa, nie wpływając przy tym na sam akt małżeński. Strony są zdolne do podjęcia współżycia, jednak niezależnie od ich woli nie może dojść do poczęcia ${ }^{73}$. „Niepłodność ani nie wzbrania zawarcia małżeństwa, ani nie powoduje jego nieważności, z zachowaniem przepisu kan. 1098”74.

\subsection{Przeszkoda różnej religii (impedimentum disparitatis cultus)}

W obecnym stanie prawnym przeszkoda różnej religii zachodzi pomiędzy dwiema osobami, z których jedna została ochrzczona w Kościele katolickim lub była do niego przyjęta, a druga jest nieochrzczona $^{75}$. Wydaje się, iż zakres wiernych ochrzczonych w Kościele katolickim nie budzi wątpliwości. Mowa o osobach, które ważnie przyjęły ten sakrament z właściwą intencją włączenia do Kościoła katolickiego. Więcej trudności może nastręczyć zdefiniowanie podmiotów, które przyjęto do Kościoła katolickiego. Pod tym pojęciem należy rozumieć osoby, które do Kościoła katolickiego zostały włączone dopiero po ważnym chrzcie udzielonym w innym Kościele lub wspólnocie kościelnej ${ }^{76}$.

72 Por. H. Stawniak, Przeszkoda niemocy płciowej, w: W. Góralski (red.), Przeszkody małżeńskie w prawie kanonicznym, Warszawa 2016, s. 123.

73 Por. J. Krzywкowsкa, Przeszkoda niemocy płciowej wświetle wykładni kan. 1084 Kodeksu Prawa Kanonicznego z 1983 roku, Studia Prawnoustrojowe 21 (2013), s. 37.

74 KPK 1983, kan. $1084 \$ 3$. Kanon 1098 stanowi: „Kto zawiera małżeństwo zwiedziony podstępem, dokonanym dla uzyskania zgody małżeńskiej, a dotyczącym jakiegoś przymiotu drugiej strony, który ze swej natury może poważnie zakłócić wspólnotę życia małżeńskiego, zawiera je nieważnie”.

75 Por. TAmżE, kan. $1086 \$ 1$.

76 Por. U. Nowicka, Przeszkoda różności religii, w: W. GóRAlski (red.), Przeszkody małżeńskie w prawie kanonicznym, , Warszawa 2016, s. 223. 
Na omówienie zasługuje treść klauzuli zawartej w kanonie 1086 \$1 KPK 1983, w której Najwyższy Prawodawca odniósł się do strony ochrzczonej bądź przyjętej do Kościoła katolickiego. Brzmiała ona następująco: „i nie odłączyła się od niego formalnym aktem”. Papież Benedykt XVI usunął ją, wydając List apostolski Omnium in mentem. Klauzula ta przysparzała wielu problemów interpretacyjnych doktrynie, jurysprudencji, a także praktyce duszpasterskiej ${ }^{77}$.

Chrzest wywiera niezatarte znamię, więc nigdy i w żaden sposób nie można zmazać jego skutków. Sakrament ten zmienia ontologicznie człowieka ${ }^{78}$. Ustawodawca kościelny zatwierdził tę przeszkodę, ponieważ pragnie ochronić wiarę strony katolickiej oraz dzieci zrodzonych z takiego związku ${ }^{79}$.

Restrykcja ta ustaje zasadniczo w dwóch przypadkach: poprzez przyjęcie chrztu lub udzielnie dyspensy ${ }^{80}$. Drugi sposób został ściśle określony w kanonie $1086 \$ 2$ KPK 1983. Dyspensy może udzielić ordynariusz miejsca, jeżeli zaistnieje słuszna i rozumna przyczyna ${ }^{81}$. Aby do tego doszło, muszą zostać spełnione trzy warunki zawarte w kanonach 1125 i 1126: 1) strona katolicka oświadcza, iż jest gotowa odsunąć od siebie niebezpieczeństwo utraty wiary; zobowiązuje się złożyć przyrzeczenie, że uczyni wszystko, co będzie w jej mocy, aby dzieci zrodzone z tego małżeństwa zostały ochrzczone i wychowane w Kościele katolickim; 2) druga strona zostaje poinformowana o przyrzeczeniach składanych przez stronę katolicką w taki sposób, aby faktycznie była świadoma treści przyrzeczenia i obowiązków małżonka; 3) obydwie strony otrzymują pouczenie o celach i istotnych przymiotach małżeństwa, których nie może wykluczyć żadna $z$ nich ${ }^{82}$. Jak konstatuje Ryszard Sztychmiler, „warunkiem dopuszczenia do ważnego

\footnotetext{
77 Por. J. GręźLikowski, Przeszkody małżeńskie..., dz. cyt., s. 77.

78 Por. J. KowAL, Comunione ecclesiastica e diritto matrimoniale, w: P.A. Bonnet, C. Gullo (red.), Diritto matrimoniale canonico, t. 3, Città del Vaticano 2005, s. 187. 79 Por. J. Fornés, Poszczególne przeszkody zrywające, dz. cyt., s. 803-804.

80 Por. G. Dzierżon, Ewolucja doktryny oraz dyscypliny dotyczacych przeszkody różności religii w kanonicznym porządku prawnym, Warszawa 2008, s. 309-310.

81 Por. KPK 1983, kan. 1125.

82 Por. TAMżE.
} 
zawarcia małżeństwa strony katolickiej z osobą nieochrzczoną jest wykazanie słusznej i rozumnej przyczyny, odpowiednie pouczenie, złożenie rękojmi i uzyskanie dyspensy ordynariusza"83.

Z kanonu 1125 KPK 1983 jasno wynika, że tylko strona katolicka zobowiązuje się do złożenia oświadczenia i przyrzeczenia. Strona niekatolicka ma być jedynie poinformowana o zobowiązaniach drugiej strony. Co więcej, nie musi się z nimi zgadzać ani ich akceptować. Wystarczy, że będzie ich świadoma ${ }^{84}$. Taka regulacja nie powinna dziwić - wszak prawodawca kościelny nie może nałożyć obowiązków na osobę, która nie podlega jego ustawom.

Kodeks nie podaje wprost sposobu złożenia zobowiązań. W tym celu został wprowadzony kanon 1126, powierzający obowiązek określenia formy oświadczeń i przyrzeczeń konferencjom biskupów. Ponadto konferencje powinny ustalić, jaką metodą ma być to stwierdzone na forum zewnętrznym, a także jak ma być o tym poinformowana strona niekatolicka ${ }^{85}$. Konferencja Episkopatu Polski w Instrukcji o przygotowaniu do zawarcia matżeństwa w Kościele katolickim zadecydowała, iż obydwie strony powinny podpisać oświadczenia i przyrzeczenia ${ }^{86}$.

Należy podkreślić, że w KPK 1983 istnieje wyraźne zróżnicowanie pomiędzy przeszkodą różności religii a ograniczeniami dotyczącymi małżeństw mieszanych (kanony 1124-1129 KPK 1983). Co ważne, w aktualnym ustawodawstwie nie obowiązują przeszkody wzbraniające, które istniały pod rządami Kodeksu Prawa Kanonicznego z 1917 r. Jak słusznie skonstatował Ginter Dzierżon, Najwyższy Prawodawca w odniesieniu do małżeństw mieszanych ustanowił jedynie zakaz

\footnotetext{
83 R. Sztychmiler, Sakramentalność małżeństwa w perspektywie prawnokanonicznej, w: A. Proniewski (red.), Studia teologii dogmatycznej, t. 2, Białystok 2016, s. 92.

84 Por. U. Nowicka, Przeszkoda różności religii, dz. cyt., s. 229.

85 Por. KPK 1983, kan. 1126.

86 Por. Konferencja EPIskopatu Polski, Instrukcja Episkopatu Polski o przygotowaniu do zawarcia małżeństwa w Kościele katolickim, 13 XII 1989, pkt 84, w: C. Krakowiak, L. Adamowicz (red.), Dokumenty duszpastersko-liturgiczne Episkopatu Polski 1966-1993, s. 198.
} 
zawierania tego typu związków, natomiast przeszkoda różności religii nadal pozostaje przeszkodą zrywającą ${ }^{87}$.

\subsection{Przeszkoda święceń (impedimentum ordinis)}

Ustawodawca kościelny zamieścił bardzo krótką dyspozycję określającą następną przeszkodę: „nieważnie usiłują zawrzeć małżeństwo ci, którzy otrzymali święcenia"88. Dotyczy to trzech stopni święceń: diakonatu, prezbiteratu i biskupstwa ${ }^{89}$. Przeszkoda ta ma swoją podstawę w kościelnym celibacie ${ }^{90}$. Choć nie należy on do istoty kapłaństwa, ma swoje przekazy w Piśmie Świętym, cieszy się tradycją sięgającą przynajmniej IV wieku, jak również był niejednokrotnie potwierdzany przez Magisterium Kościoła ${ }^{91}$. Mężczyźni, którzy przyjmują sakrament święceń, oddają się całkowicie oblubieńczej miłości Chrystusa, aby w ten właśnie sposób służyć każdemu człowiekowi ${ }^{92}$. Warunkiem zaistnienia przeszkody jest ważność święceń, bowiem w przypadku nieważności święceń przeszkoda nie powstaje. Należy jednak udowodnić ten fakt pro foro externo mocą wyroku sądowego lub dekretu administracyjnego, w którym zostanie stwierdzona nieważność przyjętych święceń ${ }^{93}$. „Usiłowanie zawarcia małżeństwa przez wyświęconego pociąga za sobą usunięcie z urzędu kościelnego, zaciągnięcie kary suspensy late sententiae oraz - gdy po odpowiednim upomnieniu kapłan nie poprawia się - możliwość wymierzenia innych kar, aż do wydalenia ze stanu duchownego"94.

\footnotetext{
87 Por. G. Dzierżon, Ewolucja doktryny..., dz. cyt., s. 311.

88 KPK 1983, kan. 1087.

89 Por. TAMżE, kan. $1009 \$ 1$.

90 Por. TAMżE, kan. 277.

91 Por. J. Fornés, Poszczególne przeszkody zrywające, dz. cyt., s. 805.

92 Por. J. RApacz, Święcenia jako przeszkoda do zawarcia małżeństwa, Analecta Cracoviensia 35 (2003), s. 504.

93 Por. T. Bialobrzeski, Przeszkoda święceń, w: W. Góralski (red). Przeszkody małżeńskie w prawie kanonicznym, Warszawa 2016, s. 255.

94 J. Fornés, Poszczególne przeszkody zrywające, dz. cyt., s. 806.
} 
Omawiana przeszkoda pochodzi z prawa kościelnego, jednak udzielenie dyspensy zastrzeżono Stolicy Apostolskiej ${ }^{95}$. Omawiając ustanie przeszkody święceń, należy stwierdzić, że może ono nastąpić w trzech różnych sytuacjach: przede wszystkim wskutek dyspensy od celibatu udzielonej przez Biskupa Rzymskiego, nieważności święceń lub utraty stanu duchownego. W drugim przypadku przeszkoda nie powstaje, jednak prawo wymaga, aby zostało to stwierdzone dekretem lub wyrokiem. Zasadniczo utrata stanu duchownego nie wiąże się automatycznie $\mathrm{z}$ dyspensą od obowiązku celibatu ${ }^{96}$.

\subsection{Przeszkoda ślubu (impedimentum voti)}

Przeszkoda wieczystego publicznego ślubu czystości złożonego w instytucie zakonnym została określona w kanonie 1088 KPK 1983. W obecnym ustawodawstwie został zniesiony podział ślubów zakonnych na uroczyste i zwykłe, dlatego też omawiana przeszkoda nosi nazwę ślubu97. W KPK 1917 śluby proste były jedynie przeszkodą wzbraniającą. Obecny zakres przeszkody jest zmodyfikowany, gdyż odnosi się do wszystkich publicznych wieczystych ślubów czystości składanych w instytutach zakonnych ${ }^{98}$.

Aby ślub - świadoma i dobrowolnie uczyniona obietnica Bogu był przeszkodą, musi polegać na dozgonnej czystości oraz zostać złożony publicznie na ręce prawowitego przełożonego $\mathrm{w}$ instytucie zakonnym rozumianym w myśl kanonu $607 \$ 2$. Śluby czasowe czy prywatne nie stanowią zatem przeszkody małżeńskiej. Profesja zakonna, która jest przeszkodą, musi zostać oczywiście ważnie złożona, z zachowaniem kanonu 658 KPK $1983^{99}$.

\footnotetext{
95 Por. KPK 1983, kan. 1078 \$2, n. 1; W. GóRALSKI, Kanoniczne prawo matżeńskie, dz. cyt., s. 132.

96 Por. T. Bialobrzeski, Przeszkoda święceń, dz. cyt., s. 259.

97 Por. W. Góralski, Kanoniczne prawo małżeńskie, dz. cyt., s. 133.

98 Por. J. GręźLikowski, Przeszkody małżeńskie..., art. cyt., s. 85.

99 Por. W. Góralski, Kanoniczne prawo małżéskie, dz. cyt., s. 134.
} 
W zależności od prawa instytutu, w którym został złożony ślub, określony jest podmiot uprawniony do dyspensowania. Jeśli wieczysty publiczny ślub czystości został złożony $\mathrm{w}$ instytucie na prawie papieskim, dyspensa jest zastrzeżona Stolicy Apostolskiej ${ }^{100}$. Analogicznie, dyspensa od takiego ślubu złożonego w instytucie na prawie diecezjalnym leży w gestii ordynariusza miejsca ${ }^{101}$.

Warto zaznaczyć, że ślub składany w stowarzyszeniu życia apostolskiego oraz instytucie świeckim, jak również prywatny ślub czystości, nie stanowią przeszkody w myśl obecnie obowiązującego prawa ${ }^{102}$.

\subsection{Przeszkoda uprowadzenia (impedimentum raptus)}

Kanon 1089 stanowi: „nie może być ważnie zawarte małżeństwo pomiędzy mężczyzną i kobietą uprowadzoną lub choćby przetrzymywaną z zamiarem zawarcia z nią małżeństwa, chyba że później kobieta uwolniona od porywacza oraz znajdująca się w miejscu bezpiecznym i wolnym, sama swobodnie wybierze to małżeństwo" ${ }^{\text {103 }}$. Kościół stoi na straży dobrowolnego wyrażania zgody małżeńskiej przez kobietę, dlatego też w sytuacji porwania lub bezprawnego przetrzymywania mężczyzna staje się niezdolnym do ważnego zawarcia małżeństwa z tą kobietą $^{104}$. Przeszkoda ustaje w momencie uwolnienia kobiety i znalezienia się jej w bezpiecznym miejscu. Restrykcja ta ma swe źródło w prawie kościelnym, dlatego też można od niej udzielić dyspensy w momencie, gdy zanikną okoliczności ograniczające wolność konsensusu uprowadzonej ${ }^{105}$. Należy wskazać, że w omawianym kanonie istnieje luka prawna, ponieważ przepis ten określa tylko przypadek porwania kobiety przez mężczyznę. W odwrotnej sytuacji, stosując literalne brzmienie przepisu, małżeństwo nie będzie dotknięte wadą,

\footnotetext{
100 Por. KPK 1983, kan. 1078 \$2, n. 1.

101 Por. TAmże, kan. $1078 \$ 1$.

102 Por. W. GóRAlski, Kanoniczne prawo małżeńskie, dz. cyt., s. 134.

103 KPK 1983, kan. 1089.

104 Por. C. Suchocki, Przeszkody matżeńskie..., dz. cyt., s. 37.

105 Por. TAMżE.
} 
a więc zostanie zawarte ważnie. Być może prawodawca kościelny stanął na stanowisku, iż słabsza płeć nie jest w stanie uprowadzić i wymusić wyrażenia zgody małżeńskiej na mężczyźnie w celu zawarcia z nim małżeństwa.

Warto dla porównania przedstawić, jak ta kwestia kształtuje się w katolickich Kościołach wschodnich. Kodeks Kanonów Kościołów Wschodnich w kanonie 806 stanowi: „Z osobą uprowadzoną lub choćby przetrzymywaną z zamiarem zawarcia z nią małżeństwa, nie można ważnie zawrzeć małżeństwa [...]”. Zgodnie z przywołanym zapisem przeszkoda ta dotyczy obydwu płci - kobiety i mężczyzny. W środowisku kanonistów pojawiają się głosy, iż normę tę powinno się stosować również w Kościele łacińskim. Takie stanowisko jednak wydaje się niesłuszne. Szerokie rozważania na ten temat podjęła Urszula Nowicka, konkludując, iż „małżeństwo zawarte przez porwanego mężczyznę wyznania rzymskokatolickiego pozostanie ważne, jeśli zaś byłby on katolikiem wschodnim - z prawa pozytywnego Kościoła jest uznany za niezdolnego do zawarcia ważnego małżeństwa"106.

\subsection{Przeszkoda występku (impedimentum criminis seu coniugicidii)}

Przeszkoda występku ${ }^{107}$ może zaistnieć w dwóch sytuacjach. Przede wszystkim odnosi się do takich okoliczności, w których ktoś w celu zawarcia małżeństwa z określoną osobą zadaje śmierć jej współmałżonkowi lub własnemu ${ }^{108}$. Ponadto „nieważnie [...] usiłują zawrzeć małżeństwo ci, którzy poprzez fizyczny lub moralny współudział spowodowali śmierć współmałżonka"109. Aby stwierdzić istnienie przeszkody w pierwszym przypadku, należy poznać intencje osoby, która spowodowała śmierć współmałżonka. Musi

\footnotetext{
106 U. NowicKa, Przeszkody matżeńskie w perspektywie międzyobrządkowej według KPK $i$ KKKW, Ius Matrimoniale 15 (21) 2010, s. 9.

107 W literaturze przedmiotu inaczej nazywana przeszkodą małżonkobójstwa.

108 Por. KPK 1983, kan. $1090 \$ 1$.

109 Tamże, kan. $1090 \$ 2$.
} 
być to świadome działanie w celu zawarcia małżeństwa. W drugim przypadku intencja nie ma znaczenia, bowiem prawodawca stanął na stanowisku, iż sam współudział w zabójstwie jest na tyle poważnym przestępstwem, że nie wymaga dodatkowego warunku. Zlecenie zabójstwa wyczerpuje znamiona występku. Musi to być czynność dokonana, samo usiłowanie czy planowanie zabójstwa nie jest przeszkodą zrywającą do małżeństwa. Przeszkoda małżonkobójstwa pochodzi z prawa kościelnego, dlatego też nie odnosi się do osób nieochrzczonych. Może odnosić się do nich pośrednio, o ile w występku brała udział również strona ochrzczona ${ }^{110}$. Udzielenie dyspensy jest zarezerwowane Stolicy Apostolskiej ${ }^{111}$.

\subsection{Przeszkoda przyzwoitości publicznej (impedimentum honestatis publicae)}

Ostatnią przeszkodą małżeńską określoną w prawie kanonicznym jest przeszkoda przyzwoitości publicznej. Podstawą omawianego obostrzenia jest nieważne małżeństwo albo notoryczny lub publiczny konkubinat ${ }^{112}$. Kanon 1093 stanowi: „Przeszkoda przyzwoitości publicznej powstaje $\mathrm{z}$ nieważnego małżeństwa po rozpoczęciu życia wspólnego albo z notoryjnego lub publicznego konkubinatu. Powoduje zaś nieważność małżeństwa w pierwszym stopniu linii prostej między mężczyzną i krewnymi kobiety i odwrotnie"113. Małżeństwem nieważnym jest takie, które ma zewnętrzny charakter małżeństwa, jednak nie zaistniał węzeł małżeński - ze względu na przeszkodę, wadę zgody lub też niezachowanie przepisanej formy zawarcia małżeństwa ${ }^{114}$. Nie ma znaczenia, czy strony mieszkają na stałe ze sobą. Nieistotne jest, czy są to osoby wolne, czy też związane

\footnotetext{
110 Por. W. Góralski, Kanoniczne prawo małżeńskie, dz. cyt., s. 139.

111 Por. KPK 1983, kan. $1078 \$ 2$, n. 2.

112 Por. W. Góralski, Kanoniczne prawo małżeńskie, dz. cyt., s. 148.

113 KPK 1983, kan. 1093.

114 Por. T. Pawluk, Prawo kanoniczne ..., dz. cyt., s. 150.
} 
węzłem małżeńskim ${ }^{115}$. Jak podkreśla się w literaturze, przeszkoda przyzwoitości publicznej ma ze swej natury charakter trwały i nie ustaje sama $\mathrm{z}$ siebie po orzeczeniu nieważności małżeństwa czy też zakończeniu konkubinatu ${ }^{116}$. Przeszkoda ta ma pochodzenie kościelne, dlatego też można od niej udzielić dyspensy ${ }^{117}$. Uprawnionym do tego jest ordynariusz miejsca.

\section{Przeszkody małżeńskie zawarte wyłącznie w Kodeksie rodzinnym i opiekuńczym}

Polski prawodawca w Kodeksie rodzinnym i opiekuńczym zamieścił w katalogu przeszkód małżeńskich dwie, które w Kodeksie Prawa Kanonicznego nie zostały uregulowane w zakresie przeszkód, lecz wad zgody ${ }^{118}$. Mowa o ubezwłasnowolnieniu całkowitym oraz chorobie psychicznej albo niedorozwoju umysłowym.

\subsection{Ubezwłasnowolnienie całkowite}

Zgodnie $\mathrm{z}$ artykułem $11 \$ 1 \mathrm{KRO}$ w związek małżeński nie może wstąpić osoba ubezwłasnowolniona całkowicie. Należy podkreślić, że zakaz ten ma charakter bezwzględny, ponieważ nigdy nie może zostać uchylony przez są ${ }^{119}$. Na temat ubezwłasnowolnienia traktuje artykuł $13 \$ 1 \mathrm{KC}$. Stanowi on, iż osoba, która ukończyła trzynaście lat, może zostać całkowicie ubezwłasnowolniona. Przesłankami do podjęcia takich kroków są: choroba psychiczna, niedorozwój umysłowy albo innego rodzaju zaburzenie psychiczne, w szczególności pijaństwo lub narkomania. Konsekwencją podanych czynników

\footnotetext{
115 Por. W. Góralski, Kanoniczne prawo małżeńskie, dz. cyt., s. 149.

116 Por. U. Nowicka, Przeszkoda przyzwoitości publicznej, w: W. Góralski (red.), Przeszkody małżeńskie w prawie kanonicznym, Warszawa 2016, s. 458.

117 Por. J. Fornés, Poszczególne przeszkody zrywające, dz. cyt., s. 811.

118 Prawodawca kościelny uregulowania dotyczące zgody małżeńskiej zawarł w kan. 1095 - 1107 KPK 1983.

119 Por. G. JęDREJEk, Zawarcie małżeństwa, dz. cyt., s. 58.
} 
musi być niezdolność kierowania własnym postępowaniem ${ }^{120}$. Co ważne, przeszkodą jest wyłącznie ubezwłasnowolnienie całkowite, gdyż w razie jego uchylenia lub zmiany na ubezwłasnowolnienie częściowe przeszkoda przestaje istnieć, a małżeństwo może zostać zawarte $^{121}$.

Oczywistym powodem wprowadzenia omawianego zakazu jest troska ustawodawcy państwowego o małżeństwo i ewentualne potomstwo zrodzone $\mathrm{z}$ takiego związku. Trudno bowiem wyobrazić sobie, aby osoba, która nie jest w stanie kierować swoim postępowaniem, mogła prawidłowo realizować obowiązki i prawa małżeńskie.

Znaczący dla omawianej przeszkody jest fakt jej istnienia przed zawarciem małżeństwa. Orzeczenie ubezwłasnowolnienia całkowitego po wstąpieniu w związek małżeński nie stanowi podstawy unieważnienia takiego małżeństwa. Legitymizację czynną do żądania unieważnienia $z$ omawianej przyczyny posiada każdy z nupturientów ${ }^{122}$.

\subsection{Choroba psychiczna albo niedorozwój umysłowy}

Drugą przeszkodą, która występuje wyłącznie w Kodeksie rodzinnym i opiekuńczym, jest choroba psychiczna albo niedorozwój umysłowy. Polski prawodawca określił ją w artykule $12 \$ 1$ zdaniu 1 KRO. Nie jest to jednak zakaz bezwzględny, ponieważ do omawianego artykułu zostało dołączone drugie zdanie. Zezwala się w nim, po uprzedniej zgodzie sądu, na zawarcie związku małżeńskiego osobie, której stan zdrowia lub umysłu nie zagraża małżeństwu ani zdrowiu przyszłego potomstwa i która nie została ubezwłasnowolniona całkowicie. Zezwolenia takiego udziela sąd w trybie postępowania nieprocesowego ${ }^{123}$. Uprawnioną do złożenia wniosku jest osoba dotknięta chorobą psychiczną lub niedorozwojem umysłowym (artykuł $561 \$ 2$ Kodeksu postępowania cywilnego).

\footnotetext{
120 Por. KC, art. $13 \$ 1$.

121 Por. J. Gajda, Unieważnienie małżeństwa, dz. cyt., s. 159.

122 Por. KRO, art. $11 \$ 2,3$ oraz G. JęDREJEK, Zawarcie małżeństwa, dz. cyt., s. 58.

123 Por. G. JęDREJEk, Zawarcie małżeństwa, dz. cyt., s. 59.
} 
Podobnie jak poprzednia przeszkoda, zakaz zawarcia związku małżeńskiego ze względu na chorobę psychiczną albo niedorozwój umysłowy został wprowadzony do KRO ze względu na troskę i chęć ochrony rodziny. Osoby cierpiące na tego typu zaburzenia nie zawsze mogą $\mathrm{w}$ pełni realizować obowiązki wynikające $\mathrm{z}$ małżeństwa. Ponadto istnieje niebezpieczeństwo, że dzieci zrodzone $\mathrm{z}$ takiego związku odziedziczą chorobę po rodzicu.

Należy zwrócić uwagę, że choroba psychiczna, niedorozwój umysłowy czy też inne zaburzenia powinny zostać stwierdzone przez biegłego psychiatrę. Aby można było unieważnić małżeństwo z tego tytułu, przypadłości te muszą wystąpić przed zawarciem związku małżeńskiego. Późniejsze popadnięcie w chorobę przez jednego ze współmałżonków nie jest podstawą do żądania unieważnienia tego związku ${ }^{124}$.

W myśl artykułu $12 \$ 2 \mathrm{KRO}$ uprawnionymi do wnioskowania o unieważnienie małżeństwa są obydwoje małżonkowie. Co istotne, małżeństwo nigdy nie może zostać unieważnione po ustaniu choroby psychicznej ${ }^{125}$. Konwalidacja jest niedopuszczalna w przypadku niedorozwoju umysłowego, gdyż jest to stan trwały, natomiast dopuszcza się ją w sytuacji zaleczenia np. pijaństwa czy też narkomanii ${ }^{126}$.

\section{Wnioski}

Konkludując, zakres przeszkód małżeńskich w prawie kanonicznym jest znacznie szerszy niż w prawie świeckim. Niemniej pięć przeszkód jest tożsamych w obydwu porządkach prawnych: przeszkoda wieku, węzła małżeńskiego, pokrewieństwa, powinowactwa oraz pokrewieństwa prawnego. Prawodawca świecki wprowadził dwie przeszkody małżeńskie, które w kościelnym prawie małżeńskim nie zostały uregulowane w zakresie przeszkód małżeńskich, lecz odnoszą się do wad zgody. Są nimi ubezwłasnowolnienie całkowite oraz

\footnotetext{
124 Por. J. Gajda, Unieważnienie mał̇̇eństwa, dz. cyt., s. 162.

125 Por. KRO art. $12 \$ 3$.

${ }^{126}$ Por. J. GajdA, Unieważnienie małżeństwa, dz. cyt., s. 167.
} 
przeszkoda choroby psychicznej lub niedorozwoju psychicznego. Przeszkody istniejące wyłącznie na gruncie prawa kanonicznego (niemocy płciowej, różnej religii, święceń, wieczystego publicznego ślubu złożonego w instytucie zakonnym, uprowadzenia, występku i przyzwoitości publicznej) zostały wprowadzone z racji szczególnej troski Kościoła o małżeństwo i rodzinę. Co oczywiste, ze względu na odmienny charakter i cel prawa państwowego, nie była możliwa ich implikacja na grunt prawa polskiego.

\section{Marital impediments in the light of Code of Canon Law and The Family and Guardianship Code}

\section{Summary}

There is no doubt that many marital impediments indicated in Code of Canon Law have not been regulated in The Family and Guardianship Code, because they result from Divine Law and from the nature of the Catholic Church. However, a part of the marital prohibitions is the same in both of these legal systems. These are most often impediments arising from natural law, to which every human is subject, regardless of national or religious affiliation. The range of marital impediments is significantly broader in Canon Law than in secular law. However, five impediments are identical in both law orders: the impediment of age, bond of marriage, consanguinity, affinity and legal consanguinity. The secular legislature implemented two marital impediments, which have not been regulated in church marital law in matters of marital impediment, but which relate to contractual defects. They are: total deprivation of liberty and the impediment of mental disorder or mental underdevelopment. Impediments existing only in canon law (impotence, difference of religion, ordination, vow, abduction, misdemeanour and public honesty) were implemented on the grounds of particular concern of the Church about marriage and the family. Obviously, due to the different nature and aim of national law, the implication of them to Polish law was not possible. 